\title{
Relationship between Money Supply, Income and Price Level in Nepal*"
}

\author{
Ram Chandra Acharya ${ }^{1}$
}

\begin{abstract}
Using the data from 1974/75 to 2017/18, this paper intended to find out the relationship between money supply, income and price level in Nepal. The paper has established the relationship between real money supply (both $M 1$ and M2) with respect to real GDP, nominal money supply (both MI and M2) with respect to price level and nominal GDP with respect to price level separately. The econometric tools such as ADF for unit root tests, SIC for lag length selection, bivariate Johansen Cointegration tests followed by VECM has been used for long-run causality. Further, VEC as well as VAR Granger Causality/Block Exogeneity Wald tests for short-run causality are used. The paper found bidirectional longrun causality between the real income with respect to both type of money supply in real terms. But there is no evidence of short run causation between these variables. Likewise, the study found the unidirectional long-run relationship runs from narrow money supply to consumer price. However, there is no short-run relationship from either side. Accordingly, there is no evidence of long-run as well as short-run relationship between broad money supply and consumer price level. Lastly, there is no evidence of long-run causality between nominal GDP and general price level. But the study found unidirectional short-run causality running from general price to nominal GDP. The results suggest that Nepal should focus on growth of time deposit component of broad money supply in long-run for economic growth and control of inflation.
\end{abstract}

Key Words: Broad and Narrow Money Supply, Price level, Short-run and Longrun Causality

JEL Classification: E51, E31, C32

* This paper is based on the Master's thesis by the author submitted to Central Department of Economics, Tribhuvan University in partial fulfillment of the requirement for the master's degree of Arts in Economics.

\# The earlier version of this paper is available at www.nrb.org.np under NRB Working Paper series, NRB-WP-46, 2019.

1 Assistant Director, Nepal Rastra Bank. E-mail: rcacharya@nrb.org.np 


\section{INTRODUCTION}

The relationship between money, income and prices has been a subject of discussion among economists for a long time. Specifically, the role of money in determination of income and prices has been debated extensively over the decades. According to the classicists, the increase in money stock shifts the aggregate demand upwards without affecting the supply side (Ackley, 2007). This increment in money supply leads to increase in price level which just offsets the increase in nominal money, leaving the real money stock unchanged. Money, then, is completely neutral in the classical economy, real output, income and other real variables are completely left unchanged by change in the money supply (Branson, 2005).

Keynesians held the view that money does not play an active role in determining income and prices. They stress on the direction of causation running from income to money without any feedback (Coddington, 1976). According to their view, changes in the stock of money supply affects the interest rate and hence investment and consumption. The effect goes through the income at last. They say changes in the stock of money supply affects income only indirectly (Shapiro, 2001). Accordingly, changes in income cause changes in the stock of money supply through change in the demand for money, given sticky interest rates (Branson, 2005). This indicates a unidirectional causality from income to money supply. Similarly, according to the Keynesians, prices are determined by the demand and supply forces. From Keynesian point of view, inflation as a real phenomenon, is caused mainly by real factors (Blinder, 1988). The Keynesian economists negate the role of money in the price change. They are of the view that changes in prices are mainly due to structural factors.

Contrary to the Keynesians, the Monetarists led by Milton Friedman faithfully claim that money supply plays an active role in determining income and prices (Laidler, 1981). This indicates that both income and prices are mainly caused by changes in the stock of money supply in the short-run. Monetarists believe that the direction of causation runs from money to income without any feedback only in the short-run and the inflation is a monetary phenomenon in that changes in money supply cause changes of prices in both short-run as well as long-run (Mayer, 1975). In clear notation, the monetarists' proposition suggests that there is a unidirectional causality from money supply to income and a unidirectional causality from money supply to prices.

The new classical point of view totally ignored the association between money supply and income in both long-run and short-run because of rational expectation hypothesis (Froyen, 2014). Rather the overall effect of change in money supply 
remains only in price level (Maddock \& Carter, 1982). Their view coincides with the classical view.

The new Keynesians are giving the strong microeconomic foundation to the Keynesian system. So, their views support the Keynesian view of indirect association between money supply, income and price (Gordon, 1990). But they are not as rigid as Keynesians to believe the effectiveness of monetary policy (Froyen, 2014).

Despite this clear dispute, it is very crucial to understand the relationship between the variables such as; income, money and prices in an economy. Understanding this relationship is important, especially to the public policymakers, in conducting effective stabilization policies. The causal relationships between money and income as well as between money and prices have been an area of active research in Economics particularly after the publication of the influential paper by Sims (1972). Based on Granger causality, Sims (1972) developed a test of causality and applied it to data from the United States to examine the causal relationship between money and income. He found the evidence of unidirectional causal relationship running from money to income supporting the Monetarists' claim.

The money supply, income and price level have increasing tendency over the years in Nepal. The average increment rate of narrow money (currency plus demand deposit), broad money (narrow money plus time deposit), GDP and price level over the last 44 years are $15.69,18.65,4.35$ and 8.19 percent respectively. Accordingly, the average growth rate of real narrow money and real broad money are 6.98 and 9.72 percent respectively. The time series macroeconomic variables are always in increasing trend. Therefore, there may be possibility of achieving the unidirectional or bilateral causal relationship between money, price and income in long-run as well as short-run. The relationship between these variables has significant importance because it traces out the nexus between these variables and provides policy implications to the policy makers. So, the main task of the study is to discuss and identify the casual relationship between these variables in the latest context of Nepal.

The problem of this study can be synthesized in the following research questions;

i. Is there any long-run and short-run relationship between these macroeconomic variables?

ii. Which variables are more appropriate for policy purpose?

The main objective of the study is to find out the long run and short run relationship between the money supply, income and the price level in Nepal. 
Additional objective is to identify the more appropriate variables for policy purpose.

There are few limitations of the study. First, there is methodological limitation of this study. The paper used Johansen Cointegration tests followed by VECM or VAR model. So, the conclusions drawn by this study may not match with the conclusions drawn by the study using other methodology. Secondly, the quarterly or monthly data are usually needed for the dynamic analysis of the model, however such GDP data were not recorded in Nepal. This study is obliged to use the annual data which may provide the less dynamic results. Third limitation of this study is that it covers only the data from 1975-2018. The reason behind using the time period is because of availability of all data series for period.

\section{REVIEW OF LITERATURE}

Friedman and Schwartz (1963) found that the changes in the behavior of the money stock had been closely related with the changes in economic activity, money income, and prices in American economy during the period from 1867 to 1960. They also found that the interaction between monetary and economic change had been highly stable. However, they observed that monetary changes often had an independent origin; they have not been simply a reflection of changes in economic activity.

Al-Jarrah (1996) investigated the nature of the linkages between money, real income, and prices in Saudi Arabia. The study used multivariate Johansen technique, Granger-causality tests, and variance decomposition and impulse response functions to test for causal relationships among variables. The results indicated that real income contributes significantly in explaining changes in the money, while the reverse was not true. Consumer prices were also significant in predicting changes in money in the kingdom. The evidence of the contribution of money in explaining prices change, however, was weak.

Holod (2000) investigated the relationships between the money supply, exchange rate and prices in the Ukrainian economy by employing the monthly data from 1995:01 to 1999:06. The study used vector autoregression (VAR), vector error correction model and impulse response functions as its methodology to show how a shock in one of the variables influences the time behavior of others. The paper found some evidence that money supply shocks affected the price level behavior, but the effect was not very strong. On the other hand, the paper found that the money supply responded significantly to the shocks in the price level.

Ahmad, Asad and Hussian (2008) used the time series data of real GDP, nominal GDP, prices and money supply for the period of 1973 to 2007. The study used ADF to test the stationary of the data series and series were found integrated of 
the order zero. The Granger causality test was used for causal relationship. The paper found the estimated coefficient between the growth of money supply and inflation to be positive and significant. The study accepted the Monetarist proposition that money supply determined the price levels and income. The authors suggested a tight monetary policy along with fiscal measures to control inflation in Pakistan.

Ishan and Anjum (2013) described the main role of money supply (M2) on GDP of Pakistan. The study used the secondary data of 12 years from 2000 to 2011. The paper found the excessive money supply (M2) by SBP (State Bank of Pakistan) entails high rate of inflation if the indicators i.e. CPI, interest rate are not controlled within the prescribed limits. The research found the evidence that high rate of inflation has adversely affected the economy of Pakistan because of excessive supply of money (M2) by SBP. The study revealed the impact of money supply (M2) on the GDP of Pakistan whereby the country has seen inflation rate in double digits. By using regression model, the paper has proved that interest rate and CPI have a significant relation with GDP. Thus, they have suggested that the money supply needs aggressive control to boost the economy.

Salih (2013) examined the relationship between the three macroeconomic variables money, income, and prices in the Saudi Arabian economy. The methodology used in the paper is cointegration, bivariate and trivariate Vector Autoregressive (VAR) models, and Granger Causality/Block Exogeneity tests. The author further supplemented the results with impulse response and variance decomposition. The results for Saudi Arabia for the period 1968-2011 indicated two-way causation between income and money supply. The results also showed that income Granger causes prices, and money Granger causes money prices.

Luo (2013) investigated the money supply behavior (endogeneity or exogeneity) of BRICS (Brazil, Russia, India, China, and South Africa) using quarterly data from 1982 to 2012. The author used the econometric methodologies like Chow Breakpoint Test, Unit Root Test, Johanson Cointegration Test, Granger causality Test, Vector Error Correction and Trivarite Vector Autocorrelation Matrix for the thesis. In four countries: Brazil, China, Russia (the period of 2004-2012) and South Africa (1982-1993), the study found money supply endogeneity evidence. Thus, this implies that bank loans cause the money supply, or there is bidirectional causality between these two. Regarding the other countries (India and the 1982-2003 period of Russia) the thesis found money supply to be exogenous which means money supply cause bank loans. The study concluded that in the short run; most of the countries share at least some degree of the monetarist view which envisages exogeneity of money supply. 
Singh, Das and Baig (2015) examined the casual relationship between money supply, output and prices of India in the short and long-term both. Different metrics for money, output and prices were used to understand the relationship between each. The paper used ADF and PP test for unit root test, EG test and Johansen test for co-integration and Granger causality test for causal relationship among variables. The paper deployed quarterly as well as monthly data for analysis. Variables to understand food inflation was especially used because food prices are less income elastic and are viewed differently by citizens. The findings of the study indicated that the relationship is sensitive to the choice of variable which is relevant in the understanding of relationship between money, output and prices. Narrow Money was found to be a better policy variable than reserve money or Broad Money in India.

Koti and Bixho (2016) have presented different approaches and theories associated with money and inflation. The paper analyzed the theoretical links between money supply and the variables such as unemployment, trade and exchange rate, taxes and wages by occupying the data of Albania from 1994 to 2015. The study used the multiple regression analysis formulated with the guidance of the theories of money. The results of the study showed the strong relationship of the money supply with economic growth, interest rate and inflation, but it had a negative sign toward inflation showing that the case of Albania was special, because of the lack of optimum money supply from the banking system and outside. So, they found that all money supplied in the economy is fully absorbed by the individuals and private sector without increasing the inflation.

Khatiwada (1994) analyzed the causal relationship between money and money income as well as money and prices by deploying the regression, the Granger's causality test and Sim's test. The paper covered the annual Nepalese data from the FY 1965/66 to 1989/90. The study found a unidirectional causality running from money to money income. The test of causality between money and prices uniformly indicated that there is unidirectional casual relation from money to prices and no feedback from prices to money.

NRB (2001) examined the money-price relationship in Nepal. The study estimated the money-price relationship by using quarterly data from third quarter of 1975 to second quarter of 1999. The study showed the delayed impact of money on prices in Nepal disapproving the theory of money and price which suggests an instantaneous relationship between money and price. The study occupied ADF to test unit root and Engel- Granger co-integration test to check long run relationship among variables. The Almon lag model was applied to ascertain the sum effects of money supply on prices over the period. The study found that 10 percent changes in M1 bring about 4.5 percent changes in prices in 
Nepal. M1 compared to M2 was found to have stronger relationship with prices in Nepal. The results of the paper also showed that there was no structural shift in money price relationship during the study period.

Gyanwaly (2012) analyzed the causal relationship between money, price and income in Asian countries by employing the annul data from 1964 to 2011. The paper used the Unit Root Test as well as the Granger's cointegration and causality test in its methodology. The study reached to the conclusion that money supply is an endogenous variable in all the countries though the extent of endogeneity in term of price and income variables slightly differs from on to another. The paper found that both narrow and broad money are unidirectionally causing the general price level in case of Nepal. The study found the bidirectional causality between broad money and GDP in Nepal. The study also found money supply in Nepal is not neutral because it is causing income and output of the economy at the cost of high inflation.

Travelling on the literature regarding the relationship between money supply and the macroeconomic variables such as income and price level, there are evidence of unidirectional as well as bidirectional causality depending on different countries. In Nepalese context, there are couple of studies done so far. These studies found unidirectional causality runs from money to price and income. So, this study is going to check the robustness of these findings. And this paper is going to use the Johansen cointegration test followed by VECM and VAR Granger causality which is purely new methodology regarding this topic in Nepalese context. And the time gap is another inspiration to study in this topic.

\section{RESEARCH METHODOLOGY}

This study is quantitative in nature and inferential research design has been used. To analyze the relationship between macroeconomic variables, the study has used the annual secondary data series from July 1975- July 2018 of Nepal. The data are collected from Quarterly Economic Bulletin 2018 and Current Macroeconomic and Financial Situation 2018 published by Nepal Rastra Bank, and various Economic Survey published by Ministry of Finance of Nepal. This study has used the data in natural logarithm form rather than in original form for analysis. The use of logarithmic transformation generates Cobb-Douglas type model and subsequently permits to interpret the coefficients as elasticities.

\subsection{Model Specification}

The study uses narrow money supply (M1), broad money supply (M2), income (GDP), and general price level (NCPI) as variables. The study has separated former three variables into nominal as well as real form for the different model. The reason behind this is to find out the relationship of real money supply with 
real income, nominal money supply with price level and price level with nominal income separately. The real variables are deflated on 2014/15 prices (By using GDP deflater instead of price level). The reason for using 2014/15 as base year is that the Household Budget Survey was conducted on 2014/15 and hence, the price level in Nepal is based on 2014/15 prices. The specific abbreviation in study would be RM1, NM1, RM2, NM2, RGDP, NGDP and NCPI for real M1, nominal M1, real M2, nominal M2, real GDP, nominal GDP and price level respectively.

\section{Relationship between Macroeconomic Variables}

Most of the theories and empirical studies suggest that the money supply causes the price level and income. The models are set as follows (Gujarati \& Sangeetha, 2007).

$$
\begin{array}{ll} 
& R G D P=f(R M) \\
\text { or, } & R G D P t=a 1+b 1 R M t+e 1
\end{array}
$$

There are two models for this relationship with narrow and broad money supply.

$$
\text { And, } N C P I=f(N M)
$$

$$
\text { or, } \quad N C P I t=a 2+b 2 N M t+e 2
$$

There are two models for the relationship between NCPI and two types of money supply as well.

Accordingly, the theory suggests that the price level causes the nominal income of a nation. So, the model is as follows.

$$
\begin{array}{ll} 
& N G D P=f(N C P I) \\
\text { or, } & N G D P t=a 3+b 3 N C P I t+e 3
\end{array}
$$

Hence, there are five bivariate models to illustrate relationship between variables in this paper.

\subsection{Methods of Analysis}

Time series econometrics has been used to estimate and analyze the coefficients. This paper intends to use the following methods of analysis.

\section{Unit Root Test}

The classical regression model assumes that the both data series of dependent and explanatory variables be stationary, i.e., the errors have a zero mean and finite variance (Enders, 2010). But in the most cases, the macroeconomic time series are non-stationary (Asteriou \& Hall, 2007). 'Whether the data is stationary or not?' we can find out by performing the unit root test. There are few methods of testing 
unit root of the data. Here, the paper has performed the Augmented Dickey-Fuller (ADF) test for the test of stationarity of the data. There are three possible forms of the ADF test (Enders, 2010);

The equation for no intercept and no trend is,

$$
\Delta \mathrm{Y}_{\mathrm{t}}=\gamma \mathrm{Y}_{\mathrm{t}-1}+\sum_{\mathrm{i}=1}^{\mathrm{P}} \beta_{\mathrm{i}} \Delta \mathrm{Y}_{\mathrm{t}-1}+\mathrm{u}_{\mathrm{t}}
$$

The equation for only intercept and no trend is,

$$
\Delta \mathrm{Y}_{\mathrm{t}}=\alpha_{0}+\gamma \mathrm{Y}_{\mathrm{t}-1}+\sum_{\mathrm{i}=1}^{\mathrm{P}} \beta_{\mathrm{i}} \Delta \mathrm{Y}_{\mathrm{t}-1}+\mathrm{u}_{\mathrm{t}}
$$

The equation for both intercept and trend is,

$$
\Delta \mathrm{Y}_{\mathrm{t}}=\alpha_{0}+\gamma \mathrm{Y}_{\mathrm{t}-1}+\alpha_{2} \mathrm{t}+\sum_{\mathrm{i}=1}^{\mathrm{P}} \beta_{\mathrm{i}} \Delta \mathrm{Y}_{\mathrm{t}-1}+\mathrm{u}_{\mathrm{t}}
$$

However, the paper has used last two equation to analyze the unit root in the data. The unit root is often denoted by order of integration I(n) (Asteriou \& Hall, 2007). The order of integration refers the number of unit roots.

\section{Schwarz Information Criterion (SIC)}

The Johansen cointegration test requires the selection of appropriate lag length. There are many ways of selecting the lag length of the model. Some scholars prefer the ad-hoc methods (Gyanwaly, 2012) and some are employing different techniques developed by the econometricians. The one of the most popular methods of selecting the lag length is Schwarz Information Criterion (SIC), specially, when the sample size is smaller (Luo, 2013). In this criterion, the lower the value, the better the model (Gujarati \& Sangeetha, 2007). This study has fixed the lag length of the model based on the SIC.

The SIC is given as (Gujarati \& Sangeetha, 2007);

$$
\mathrm{SIC}=\mathrm{n}^{\mathrm{k} / \mathrm{n}} \frac{\sum_{\mathrm{u}}^{\hat{\mathrm{u}}^{2}}}{\mathrm{n}}=\mathrm{n}^{\mathrm{k} / \mathrm{n}} \frac{\mathrm{RSS}}{\mathrm{n}}
$$

or, in $\log$ form

$$
\ln \mathrm{SIC}=\frac{\mathrm{k}}{\mathrm{n}} \ln \mathrm{n}+\ln \left(\frac{\mathrm{RSS}}{\mathrm{n}}\right)
$$

\section{Johansen Cointegration Test}

The cointegration refers the existence of a long-run equilibrium relationship between the variables in which an economic system converges over time (Bhusal, 
2016). In general, for the cointegration test, the all data series used in the model should be integrated in same order. While testing the cointegration one cannot use the first difference data rather should use the level data. So, cointegration becomes an over-riding need for any econometric modelling occupying the non-stationary time series (Asteriou \& Hall, 2007).

The most powerful and reliable method of testing the cointegration between the variables is Johansen Cointegration test. Cointegration only tells about long-run relationship between the series but it does not fix the direction of such relationship (Luo, 2013). For Johansen cointegration test, Trace statistics and Maximal Eigenvalue statistics are used which can be expressed as follows (Luo, 2013), (Asteriou \& Hall, 2007);

$$
\begin{aligned}
& \lambda \operatorname{Trace}(r)=\mathrm{T} \sum_{\mathrm{i}=\mathrm{r}+1}^{\mathrm{g}} \ln \left(1-\hat{\lambda}_{\mathrm{i}}\right) \\
& \lambda \operatorname{Max}(\mathrm{r}, \mathrm{r}+1)=^{-\mathrm{T} \ln \left(1-\hat{\lambda}_{\mathrm{r}+1}\right)}
\end{aligned}
$$

The bivariate Johnsen cointegration test has been performed in this study. When the data are found to be co-integrated, the study has performed the Vector Error Correction Method for long-run and short-run relation between variables. When the data are not co-integrated, the unrestricted Vector Autoregressive Model has been used for short-run relationship.

\section{Vector Error Correction Method (VECM)}

VECM is used for cointegrating model with first-difference stationary data. It can be used to test the short-run and long-run causality between a dependent and an explanatory variable: the long-run causality (from explanatory variable to dependent variable) can be identified in the test of the significance of the errorcorrection coefficient of the VECM by using ordinary least squares (OLS) estimation of the model (Luo, 2013). For instance, the VECM equation for the RGDP and RM is as follows (Asteriou \& Hall, 2007);

For example, the bivariate error correction model as RGDP as dependent and RM as explanatory variable is given as:

$$
\Delta \mathrm{RGDPt}_{=} \alpha_{0}+\sum_{\mathrm{i}=1}^{\mathrm{n}} \alpha_{1 \mathrm{i}} \Delta \mathrm{RGDP}_{\mathrm{t}-1}+\sum_{\mathrm{i}=1}^{\mathrm{n}} \alpha_{2 \mathrm{i}} \Delta \mathrm{RM}_{\mathrm{t}-1}+\sum_{\mathrm{i}=1}^{\mathrm{n}} \alpha_{3 \mathrm{i}} \Delta \mathrm{EC}_{\mathrm{t}-\mathrm{n}}+\mathrm{e}_{\mathrm{i}}
$$

For the long run causality form RM to RGDP $\alpha_{3 \mathrm{i}}$ must be significant. 


\section{Unrestricted Vector Autoregressive (VAR) Model}

The models which are not co-integrated has been tested short run causality under unrestricted VAR. As the data are integrated of first order, the first-difference data have been used for the VAR models. The equation of bivariate VAR models are as follows (Asteriou \& Hall, 2007);

$$
\begin{aligned}
& \Delta \mathrm{RGDPt}=\beta 10-\beta 12 \Delta \mathrm{RMt}+\gamma 11 \Delta \mathrm{RGDPt}-1+\gamma 12 \Delta \mathrm{RMt}-1+\text { uyt } \\
& \Delta \mathrm{RMt}=\beta 20-\beta 21 \Delta \mathrm{RGDPt}+\gamma 21 \Delta \mathrm{RGDPt}-1+\gamma 22 \Delta \mathrm{RMt}-1+\mathrm{uxt}
\end{aligned}
$$

\section{Granger Causality Test}

The Granger causality/ block exogeneity Wald test has been performed under both VECM and VAR for the short-run causality between the variables. For instance, the Granger causality test between real income and real money supply is given as (Gujarati \& Sangeetha, 2007);

$$
\begin{aligned}
& \triangle R G D P t=\sum_{i=1}^{n} \text { bi } \triangle R M(t-i)+\sum_{j=1}^{n} \text { ci } \triangle R G D P(t-j)+e 2 t \\
& \Delta R M t=\sum_{i=1}^{n} \text { gi } \Delta R M(t-i)+\sum_{j=1}^{n} h i \Delta R G D P(t-j)+e 3 t
\end{aligned}
$$

Where $\mathrm{e}_{2 \mathrm{t}}$ and $\mathrm{e}_{3 \mathrm{t}}$ are disturbances and assumed to be uncorrelated to each other.

Unidirectional causality from RM to RGDP is indicated if $\Sigma b_{\mathrm{i}} \neq 0$ and $\Sigma \mathrm{h}_{\mathrm{i}}=0$. Conversely, unidirectional causality from RGDP to RM exists if $\Sigma \mathrm{b}_{\mathrm{i}}=0$ and $\Sigma \mathrm{h}_{\mathrm{i}} \neq 0$. Feedback or bilateral causality is suggested if both coefficients $\Sigma b_{i} \neq 0$ and $\Sigma h_{i} \neq 0$. Finally, independence is suggested if $\Sigma b_{i}=0$ and $\Sigma h_{i}=0$. (Gujarati \& Sangeetha, 2007).

The Granger causality test for other models are also same as above.

\section{Residual Test}

The serial correlation is tested by using Breusch- Godfrey Serial Correlation LM tests in this study. The heteroscedasticity is checked by using Breusch-Pagan Godfrey test. Accordingly, Jarque-Bera test is used to test the normality of residuals. Similarly, Cumulative Sum test and cumulative sum of square test are used to test the stability of the models.

\section{EMPIRICAL ANALYSIS}

\subsection{Results of Unit Root Test}

The Augmented Dickey-Fuller (ADF) is used to test the unit root of the dependent and explanatory variables. Table 4.1 shows the results of Augmented DickeyFuller tests of the time series variables used in this study. 
Table 4.1: Results of Augmented Dickey-Fuller Tests

\begin{tabular}{|c|c|c|c|c|c|}
\hline \multirow{3}{*}{ Variable } & \multicolumn{2}{|c|}{ Level } & \multicolumn{2}{c|}{ First Difference } & \multirow{2}{*}{$\begin{array}{c}\text { Order of } \\
\text { Integration }\end{array}$} \\
\cline { 2 - 5 } & $\begin{array}{c}\text { Intercept } \\
\text { without trend }\end{array}$ & $\begin{array}{c}\text { Intercept } \\
\text { with trend }\end{array}$ & $\begin{array}{c}\text { Intercept } \\
\text { without trend }\end{array}$ & $\begin{array}{c}\text { Intercept } \\
\text { with trend }\end{array}$ & \\
\hline LNGDP & 0.133 & -1.418 & $-4.780^{*}$ & $-4.714^{*}$ & I (1) \\
& {$[0.9647]$} & {$[0.8414]$} & {$[0.0003]$} & {$[0.0025]$} & \\
\hline LRGDP & -0.484 & -3.236 & $-6.557^{*}$ & $-6.525^{*}$ & I (1) \\
& {$[0.9841]$} & {$[0.0911]$} & {$[0.0000]$} & {$[0.0000]$} & \\
\hline LNCPI & -1.527 & -1.334 & $-4.923^{*}$ & $-5.073^{*}$ & I (1) \\
& {$[0.5105]$} & {$[0.8653]$} & {$[0.0002]$} & {$[0.0009]$} & \\
\hline LNM1 & -0.845 & -1.565 & $-6.247^{*}$ & $-6.354^{*}$ & I (1) \\
& {$[0.7958]$} & {$[0.7904]$} & {$[0.0000]$} & {$[0.0000]$} & \\
\hline LRM1 & -0.825 & -4.084 & $-7.030^{*}$ & $-6.999^{*}$ & I (1) \\
& {$[0.8017]$} & {$[0.0130]$} & {$[0.0000]$} & {$[0.0000]$} & \\
\hline LNM2 & -0.617 & -2.076 & $-4.639^{*}$ & $-4.618^{*}$ & I $(1)$ \\
& {$[0.8559]$} & {$[0.5436]$} & {$[0.0005]$} & {$[0.0032]$} & \\
\hline LRM2 & -0.916 & -3.883 & $-6.033^{*}$ & $-5.929^{*}$ & I (1) \\
& {$[0.7735]$} & {$[0.0214]$} & {$[0.0000]$} & {$[0.0001]$} & \\
\hline
\end{tabular}

Source: writer's own calculation using e-views 9

Note:

1. HO: has a unit root (non-stationary) H1: does not has a unit root (stationary)

2. $\quad$ Star * shows 1 percent level of significance

3. The p-values are based on MacKinnon (1996) one-sided p-values

Table 4.1 shows that LNGDP, LRGDP, LNCPI, $\mathrm{LNM}_{1}, \mathrm{LRM}_{1}, \mathrm{LNM}_{2}$ AND $\mathrm{LRM}_{2}$ have unit root at 1 percent level of significance in both intercept with trend and without trend in the form of level data. So, the variables are not stationary at level. However, all these variables are stationary at 1 percent level of significance in first difference form in both intercept with trend and without trend. It means all the variables are integrated of order 1. i.e. I (1). Hence, the variables can be used for Johansen Cointegration test.

\subsection{Lag Length Selection}

Table 4.2 has presented the lag length selection of different models under Schwartz Information Criterion (SIC). 
Table 4.2: Optimal Lag Length Selection for Johansen Cointegration Tests

\begin{tabular}{|l|l|c|c|}
\hline \multicolumn{2}{|c|}{ Model } & \multicolumn{2}{c|}{ Lag length selection } \\
\hline Dependent & Explanatory & Lags & SIC \\
\hline LRGDP & LRM1 & 1 & $-7.781^{*}$ \\
\hline LRGDP & LRM2 & 1 & $-7.862^{*}$ \\
\hline LNCPI & LNM1 & 1 & $-6.869^{*}$ \\
\hline LNCPI & LNM2 & 1 & $-7.131^{*}$ \\
\hline LNGDP & LNCPI & 1 & $-7.378^{*}$ \\
\hline
\end{tabular}

Source: writer's own calculation using e-views 9

Note: "shows the minimum SIC value, where the corresponding lag length is optimal for the model.

Table 4.2 shows that all five models in this study can be tested by using lag length 1 which is suggested by Schwartz Information Criterion (SIC).

\subsection{Results of Johansen Cointegration Tests}

Since all the variables used are I (1), cointegration test can be done for the models. The lag length for all the models is uniformly one. There are five models in this study. Now, the next task is to perform Johansen Cointegration tests for all bivariate models in this study one by one.

Table 4.3: Results of Johansen Cointegration Tests for LRGDP and LRM1

\begin{tabular}{|l|c|c|c|c|}
\hline $\begin{array}{c}\text { Hypothesized No. } \\
\text { of CE(s) }\end{array}$ & Trace Statistics & $\begin{array}{c}\text { p-value for trace } \\
\text { statistics }\end{array}$ & $\begin{array}{c}\text { Max-Eigenvalue } \\
\text { statistics }\end{array}$ & $\begin{array}{c}\text { p-value for Max- } \\
\text { Eigenvalue }\end{array}$ \\
\hline None & $26.936^{*}$ & 0.0006 & $26.846^{*}$ & 0.0003 \\
\hline At most 1 & 0.089 & 0.7651 & 0.089 & 0.7651 \\
\hline
\end{tabular}

Source: writer's own calculation using e-views9

Notes:

1. Star * denotes the rejection of hypothesis at 1 percent level of significance

2. The p-values are MacKinnon-Haug-Michelis (1999) p-values

Table 4.3 presents the results of Johansen cointegration tests for the model 1 where there are two variables LRGDP and LRM1. The both trace statistic and max-eigenvalue tests show one cointegrating equation at 1 percent level of significance. It shows that there is long run association between real GDP and real narrow money supply. The VECM for model 1 is performed in the section 4.4.

Table 4.4: Results of Johansen Cointegration Tests for LRGDP and LRM2

\begin{tabular}{|l|l|l|l|l|}
\hline $\begin{array}{c}\text { Hypothesized No. } \\
\text { of CE(s) }\end{array}$ & Trace Statistics & $\begin{array}{c}\text { p-value for trace } \\
\text { statistics }\end{array}$ & $\begin{array}{c}\text { Max-Eigenvalue } \\
\text { statistics }\end{array}$ & $\begin{array}{c}\text { p-value for Max- } \\
\text { Eigenvalue }\end{array}$ \\
\hline None & 14.242 & 0.0765 & $14.26^{*}$ & 0.0550 \\
\hline At most 1 & 0.241 & 0.6238 & 3.84 & 0.6238 \\
\hline
\end{tabular}

Source: writer's own calculation using e-views 9

Notes:

1. Star * denotes the rejection of hypothesis at 10 percent level of significance

2. The p-values are MacKinnon-Haug-Michelis (1999) p-values 
Table 4.4 shows the results of Johansen cointegration tests for the model with LRGDP and LRM2. The Maximum Eigenvalue statistic suggests that there is one cointegrating equation at 10 percent level of significance. So, there can be a long run relationship between RGDP and RM2. The VECM for model 2 is performed in the section 4.4 .

Table 4.5: Results of Johansen Cointegration Tests for LNCPI and LNM1

\begin{tabular}{|l|l|l|l|l|}
\hline $\begin{array}{c}\text { Hypothesized No. } \\
\text { of CE(s) }\end{array}$ & $\begin{array}{c}\text { Trace } \\
\text { Statistics }\end{array}$ & $\begin{array}{c}\text { p-value for trace } \\
\text { statistics }\end{array}$ & $\begin{array}{c}\text { Max-Eigenvalue } \\
\text { statistics }\end{array}$ & $\begin{array}{c}\text { p-value for Max- } \\
\text { Eigenvalue }\end{array}$ \\
\hline None & 8.568 & 0.4068 & 5.818 & 0.6366 \\
\hline At most 1 & $2.749^{*}$ & 0.0973 & $2.749 *$ & 0.0973 \\
\hline
\end{tabular}

Source: writer's own calculation using e-views 9

Notes:

1. Star ${ }^{*}$ denotes the rejection of hypothesis at 10 percent level of significance

2. The p-values are MacKinnon-Haug-Michelis (1999) p-values

The results of Johansen cointegration tests for the model with LNCPI and LNM1 have been shown in table 4.5. The both statistics suggest that there is one cointegrating equation at 10 percent level of significance. So, the study has found that there is a long run association between RGDP and RM2. The VECM for model 3 is performed in the section 4.4 .

Table 4.6: Results of Johansen Cointegration Tests for LNCPI and LNM2

\begin{tabular}{|l|l|l|l|l|}
\hline $\begin{array}{c}\text { Hypothesized No. } \\
\text { of CE(s) }\end{array}$ & $\begin{array}{c}\text { Trace } \\
\text { Statistics }\end{array}$ & $\begin{array}{c}\text { p-value for trace } \\
\text { statistics }\end{array}$ & $\begin{array}{c}\text { Max-Eigenvalue } \\
\text { statistics }\end{array}$ & $\begin{array}{c}\text { p-value for Max- } \\
\text { Eigenvalue }\end{array}$ \\
\hline None & 3.756 & 0.9222 & 3.515 & 0.9066 \\
\hline At most 1 & 0.240 & 0.6236 & 0.241 & 0.6236 \\
\hline
\end{tabular}

Source: writer's own calculation using e-views 9

Notes:

1. Star * denotes the rejection of hypothesis at 10 percent level of significance

2. The p-values are MacKinnon-Haug-Michelis (1999) p-values

In Table 4.6, the results of Johansen cointegration tests for the model with LNCPI and LNM2 has been shown. The both statistics suggest that there is no cointegrating equation at 10 percent level of significance. So, there is no long run relationship between NCPI and NM2. So, the unrestricted VAR Granger causality is performed for the short run causality of the model 4 in section 4.5 .

Table 4.7: Results of Johansen Cointegration Tests for NGDP and NCPI

\begin{tabular}{|l|c|c|c|c|}
\hline $\begin{array}{c}\text { Hypothesized No. } \\
\text { of CE(s) }\end{array}$ & Trace Statistics & $\begin{array}{c}\text { p-value of trace } \\
\text { statistics }\end{array}$ & $\begin{array}{c}\text { Max-Eigenvalue } \\
\text { Statistics }\end{array}$ & $\begin{array}{c}\text { p-value for max- } \\
\text { eigenvalue }\end{array}$ \\
\hline None & 9.431 & 0.3270 & 9.061 & 0.2811 \\
\hline At most 1 & 0.371 & 0.5426 & 0.371 & 0.5426 \\
\hline
\end{tabular}

Source: writer's own calculation using e-views 9

Notes:

1. Star * denotes the rejection of hypothesis at 10 percent level of significance

2. The p-values are MacKinnon-Haug-Michelis (1999) p-values 
In Table 4.7, the results of Johansen cointegration test for the model with LNGDP and LNCPI is presented. The both statistics suggest that there is no long run association between NGDP and NCPI in Nepal. So, the unrestricted VAR Granger causality has been performed for the short run causality of the model 5 in section 4.5 .

\subsection{Results of VECM Results}

The long-run causality of cointegrating variables has been tested with the help of Vector Error Correction Model (VECM) framework. It is found that the bivariate models with LRGDP and LRM1, LRGDP and LRM2 as well as LNCPI and LNM1 have the long-run cointegrating relationship.

Table 4.8: Results of VECM long run causality of the cointegrating model

\begin{tabular}{|c|c|c|c|c|c|c|c|}
\hline Model & $\begin{array}{c}\text { Dependent } \\
\text { variable }\end{array}$ & $\begin{array}{c}\text { Explanatory } \\
\text { variable }\end{array}$ & $\begin{array}{l}\text { Coefficient of } \\
\text { CE }\end{array}$ & $\begin{array}{c}\text { Standard } \\
\text { error }\end{array}$ & t-statistics & p-value & \begin{tabular}{|c|}
$\begin{array}{c}\text { Direction of } \\
\text { causality }\end{array}$ \\
\end{tabular} \\
\hline \multirow[t]{2}{*}{1} & LRGDP & LRM1 & $-0.191^{*}$ & 0.0688 & -2.7700 & 0.0070 & \multirow{2}{*}{$\begin{array}{l}\text { Bi-directional } \\
\text { long-run } \\
\text { causality }\end{array}$} \\
\hline & LRM1 & LRGDP & $-0.532 *$ & 0.1148 & -4.6351 & 0.0000 & \\
\hline \multirow[t]{2}{*}{2} & LRGDP & LRM2 & $-0.192 *$ & 0.0721 & -2.6602 & 0.0095 & \multirow{2}{*}{$\begin{array}{l}\text { Bi- directional } \\
\text { long-run } \\
\text { causality }\end{array}$} \\
\hline & LRM2 & LRGDP & $-0.229 * *$ & 0.0880 & -2.6029 & 0.0111 & \\
\hline \multirow[t]{2}{*}{3} & LNCPI & LNM1 & $-0.175 * * *$ & 0.0928 & -1.8836 & 0.0635 & \multirow{2}{*}{$\begin{array}{l}\text { Uni- } \\
\text { directional } \\
\text { long-run } \\
\text { causality from } \\
\text { NM1 to NCPI }\end{array}$} \\
\hline & LNM1 & LNCPI & -0.077 & 0.0812 & -0.9425 & 0.3489 & \\
\hline \multicolumn{8}{|c|}{$\begin{array}{l}\text { Source: writer's own calculation by using e-views } 9 \\
\text { Note: }\end{array}$} \\
\hline \multicolumn{8}{|c|}{$\begin{array}{l}\text { 1. Star * indicates the rejection of null hypothesis at } 1 \% \text { level of significance, ** indicates the rejection of } \\
\text { null hypothesis at } 5 \% \text { level of significance and *** indicates the rejection of null hypothesis at } 10 \% \\
\text { level of significance. }\end{array}$} \\
\hline
\end{tabular}

Table 4.8 shows the results of the VECM long-run causality tests of the cointegrationg models. The coefficient of CE is negative in all three models. It means the cointegrating relationship between variables is convergent and valid for model 1, 2 and 3. In the model 1, the study found the bidirectional causal relationship between real GDP and the real narrow money supply in the long-run at 5 percent level of significance. Similarly, in the model 2, there is long-run bidirectional causal relationship between real GDP and real LRM2 at 5 percent level of significance. However, in the model 3, there is a unidirectional causal relationship between NCPI and the LNM1 in the long-run at 10 percent level of significance. It means RGDP causes RM1 and RM2 in the long-run with strong feedback effect. However, NCPI causes NM1in the long-run without any feedback. 
Now, the short-run causality between the variables in these three models is presented in Table 4.9 where the results of Vector Error Correction Granger Causality/ Block Exogeneity Wald tests have been shown.

Table 4.9: Results of VEC Granger Causality/ Block Exogeneity Wald tests for short-run causality

\begin{tabular}{|l|l|c|c|c|c|}
\hline \multirow{2}{*}{ Model } & \multicolumn{1}{|c|}{$\begin{array}{c}\text { Dependent } \\
\text { variable }\end{array}$} & $\begin{array}{c}\text { Explanatory } \\
\text { variable }\end{array}$ & $\begin{array}{c}\text { Chi-square } \\
\text { statistics }\end{array}$ & p-value & $\begin{array}{c}\text { Direction of } \\
\text { causality }\end{array}$ \\
\hline \multirow{2}{*}{1} & DLRGDP & DLRM1 & 0.8633 & 0.3855 & No short-run \\
& DLRM1 & DLRGDP & 0.7725 & 0.3794 & causality \\
\hline \multirow{2}{*}{2} & DLRGDP & DLRM2 & $9.43 \mathrm{E}-05$ & 0.9923 & No short-run \\
& DLRM2 & DLRGDP & 0.5440 & 0.4608 & causality \\
\hline \multirow{2}{*}{3} & DLNCPI & DLNM1 & 0.3317 & 0.5647 & No short-run \\
\cline { 2 - 5 } & DLNM1 & DLNCPI & 0.0601 & 0.8063 & causality \\
\hline
\end{tabular}

Source: writer's own calculation by using e-views 9

Note: Star *** indicates the rejection of null hypothesis at $10 \%$ level of significance.

Table 4.9 shows that there is no short-run causation between variables in all three cointegrating models. In this test, chi-square statistics is used and the p-values of the all models which are more than $10 \%$ suggest that the null hypothesis of 'there is no short-run causality' cannot be rejected. It means the growth rates of the variables in the model 1, 2 and 3 do not cause each other.

So, in a nutshell, the study infers that there is bidirectional causality between real GDP and both form of real money supply. And there is unidirectional causality runs from nominal money supply to NCPI. However, there is no causal relationship between growth rates of the variables used in model 1, 2 and 3 .

\subsection{Results of Unrestricted VAR Results}

In this heading, the short-run causal relationship between the variables of the bivariate models which are found to be not cointegrated in the long-run are investigated. While testing the long-run association of the variables in the section 4.3, the model with NCPI and NM2 as well as NGDP and NCPI do not have the long-run relationship. However, it is mandatory task for this study to go for the short-run causality investigation of the variables.

Table 4.10: Results of VAR Granger Causality/Block Exogeneity Wald tests

\begin{tabular}{|l|l|c|c|c|c|}
\hline \multirow{2}{*}{ Model } & $\begin{array}{c}\text { Dependent } \\
\text { variable }\end{array}$ & $\begin{array}{c}\text { Explanatory } \\
\text { variable }\end{array}$ & $\begin{array}{c}\text { Chi-square } \\
\text { statistics }\end{array}$ & p-value & \multirow{2}{*}{ Direction of causality } \\
\hline \multirow{2}{*}{4} & DLNCPI & DLNM2 & 1.6980 & 0.1926 & \multirow{2}{*}{ No short-run causality } \\
\cline { 2 - 5 } & DLNM2 & DLNCPI & 1.4251 & 0.2326 & \\
\hline 5 & DLNGDP & DLNCPI & $5.6933^{* *}$ & 0.0170 & $\begin{array}{c}\text { Unidirectional short-run } \\
\text { causality from NCPI to } \\
\text { NGDP }\end{array}$ \\
\cline { 2 - 4 } & DLNCPI & DLNGDP & 0.0651 & 0.7987 & N \\
\hline
\end{tabular}

Source: writer's own calculation by using e-views 9

Note: Star ** indicates the rejection of null hypothesis at $5 \%$ level of significance. 
In Table 4.10, the results of Vector Auto Regressive (VAR) Granger Causality/Block Exogeneity Wald tests for short-run causality has been performed. It is found that there is no short-run causal relationship between NCPI and NM2. However, the test shows that the unidirectional causality runs from NCPI to NGDP in the short-run at 5\% level of significance. It means the growth rate of NCPI (inflation) and growth rate of NM2 do not have any association but the inflation causes growth rate of NGDP without any feedback.

\subsection{Residual Diagnostic of the Models}

\section{Serial Correlation Test}

The Breusch-Godfrey Serial Correlation LM Test shows that there is no any serial correlation problem in any model used in this study as the p-value are more than 5 percent.

\section{Results of Heteroscedasticity Test}

The Breusch- Pagan Godfrey test is used to detect heteroskedasticity. There is no any problem of Heteroskedasticity in any model used in this study as the p-values are more than 5 percent. So, the residuals have equal variance.

\section{Results of Normality Test}

The sample period is just 44 which may not be enough for time series analysis. So, the residuals are not found normally distributed except model 5. The JarqueBera statistics was used to test normality.

\section{Results of Stability Test}

The stability of the model is tested by using CUSUM and CUSUM square tests. The test shows that the models are stable though in some model the red line is crossed which violets the 5 percent critical bound.

\section{CONCLUSIONS AND RECOMMENDATIONS}

The study reveals that there is bidirectional long-run casualty between RGDP and RM1 as well as RGDP and RM2. So, it is to conclude that in the long-run the real money supply causes the real GDP and reciprocates (without causing in the shortrun) in Nepal. In other words, the money supply causes the income in the long-run with strong feedback effect. But there is no evidence of short run causation between these two variables. It means the growth rate of real money supply and real GDP in Nepal is not associated.

Likewise, the study has found the unidirectional long-run relationship runs from NM1 to NCPI. However, there is no short-run relationship from either side. Here, 
it is to conclude that, the NM1 causes the NCPI of the country in the long-run without any feedback. But there is no evidence of long-run as well as short-run relationship between NM2 and NCPI. It concludes that there is no association between NM2 and NCPI of Nepal in both short and long run. From the both shortrun results between money supply and inflation, it can be inferred that there is no evidence of short-run causal relationship between the growth rate of money supply and inflation in Nepal.

Accordingly, there is no evidence of long-run causality between nominal GDP and NCPI. But the study found the unidirectional short-run causality running from general price to nominal GDP. It means that the growth rate of general price level affects the growth rate of nominal income of the nation.

The conclusions of the study do not support the monetarists' point of view which suggests that there is causal relationship runs from money supply to income and price in the short-run. They also postulate that the causality disappears in the longrun. Contrary to this, the paper found that the money supply causes national income with strong feedback effect and price level without feedback in the longrun.

This study also denied the early Keynesians' ignorance to the important role of money supply in the economy. However, this study supports the Keynesian view of indirect (long-run) relationship between the money supply, real income and prices. So, the conclusion of this study suggests that the money supply has significant role in the long-run rather than short- run for Nepalese economy.

This study intends to make some inferences which may be useful for the policymakers to design appropriate policies for the nation. The major recommendations of this study can be prescribed as follows;

- The study found that both real money supply causes the real income of the nation and real income also causes the both real money supply in the longrun. So, the policymakers should focus on growth rate of money supply in real term to achieve the real income growth.

- On the one hand, the main cause of the growth of nominal income of Nepal is growth rate of the general price level. On the other hand, the nominal narrow money causes the price level in the long-run. It means that the policymakers can infer that the nominal narrow money supply causes the nominal income of the nation indirectly. Hence, the narrow money supply can be instrumental to handle the inflation and nominal growth rate in the long-run.

- From the results of this study, the policymakers can see that the broad money supply is more appropriate than the narrow money supply because both causes the real income in the long-run but narrow money causes 
inflation as well. The increment in broad money supply is found healthier than narrow money supply for overall Nepalese economy. Hence, the monetary policy should focus to increase the time deposit rather than the currency and demand deposit in the economy.

\section{REFERENCES}

Ackley, G. 2007. Macroeconomic Theory (first Indian reprint ed.). Delhi: Surjeet Publications.

Ahmad, N., Asad, I., and Z. Hussian, 2008. "Money, Prices, Income and Causality: A case study of Pakistan." The Journal of Commerce 4(4).

Al-Jarrah, M. 1996. "Money, Income and prices in Saudi Arabia : a cointegration and causality analysis." Pakistan Economic and Social Review 34(1): 41-53.

Asteriou, D., and S.G. Hall. 2007. Applied Econometrics (first revised ed.). New York: Palgrave Macmillan.

Bhusal, T. P. 2016. Basic Econometrics (revised ed.). Kathmandu: Dreamland Publication (P) Ltd.

Blinder, A. S. 1988. "The fall and Rise of Keynesian Economics." Economic Record, 278-294.

Branson, W. H. 2005. Macroeconomic Theory and Policy (first East-West press ed.). New Delhi: East-West Press.

Coddington, A. 1976. "Keynesian Economics: The Search for First Principle." Journal of Economic literature: 1258-73.

Enders, W. 2010. Applied Econometric Time Series (third ed.). New Jersey: willy.

Friedman, M., and A. Schwartz. 1963. A Monetary History of the United States 18671960. Princeton Univercity Press.

Froyen, R. T. 2014. Macroeconomics, Theories and Policies (tenth ed.). Noida: Pearson India Education Services.

Gordon, R. J. 1990. "What is New-Keynesian Economics?" Journal of Economic Literature.

Gujarati, D. N., and Sangeetha. 2007. Basic Econometrics (fourth ed.). New Delhi: The McGraw-Hill Companies.

Gyanwaly, R. P. 2012. "Causal Relationship between Money, Price and Income in Asian countries (1964-2011)." The Economic Journal of Nepal 35(1): 12-31.

Holod, D. 2000. "The Relationship between Price Level, Money Supply and Exchange Rate in Ukraine." National University of Kiev-Mohyla Academy. 
Ishan, I., and S. Anjum. 2013. "Impact of Money Supply (M2) on GDP of Pakistan." Global Journal of Management and Business Research Finance 13(6).

Khatiwada, Y. R. 1994. "Some Aspects of Monetary Policy in Nepal." New Delhi: South Asian Publishers.

Koti, C. S., and T. Bixho. 2016. "Theories of Money Supply: The Relationship of Money Supply in a Period of Time T-1 and Inflation in Period T- Empirical Evidence from Albania." European Journal of Multidisciplinary Studies 1(1).

Laidler, D. 1981. "Monetarism: an Interpretation and an Assessment." Economic Journal, 1-28.

Luo, P. 2013. "Money supply behaviour in 'BRICS' economies." Jonkoping University.

Maddock, R., and M. Carter. 1982. "A Child Guide to Rational Expectations." Journal of Economic Literature, 39-51.

Mayer, T. 1975. "The Structure of Monetarism." Kredit and Kapital.

Ministry of Finance. Economic Survey, various issues. Ministry of Finance, Government of Nepal.

NRB. 2018. Current Macroeconomic and Financial Situation.

NRB. 2015. Household Budget Survey 2014/15.

NRB. 2001. "Money and Price Relationship in Nepal: A Revisit." Economic Review: Occasional Paper 13(1): 50-65.

NRB. 2018. Quarterly Economic Bulletin.

Salih, M. A. 2013. "Money, Income and Prices in Saudi Arabia." Global Journal of Management and Business research 13(1): 33-42.

Shapiro, E. 2001. Macroeconomic Analysis (fifth ed.). New Delhi: Galgotia Publications Pvt. Ltd.

Sims, C. G. 1972. "Money, Income and Causality." The American Economic Review 62(4): 540-552.

Singh, C., Das, R., and J. Baig. 2015. "Money, Output and Prices in India." IIMBWorking Paper 497. 